\title{
Asteridiella micheliifolia var. macrospora var. nov. from Vagamon hills, Kerala, India
}

\author{
Hina Mohamed and Jacob Thomas* \\ Post graduate and Research Department of Botany, Mar Thoma College, Tiruvalla- 689103, Kerala, India. \\ *Corresponding authorEmail :jacobnthomas@gmail.com \\ (Submitted on February 15,2020; Accepted on May 2, 2020)
}

\begin{abstract}
During fungal exploration of Vagamon hills of Western Ghats in Kerala state, India, Michelia champaka L. (Magnoliaceae) was found infected with a black mildew fungus. Critical microscopic examination of the fungus revealed that it is a new variety of Asteridiella micheliifolia Hosag. et al., which has larger ascospores when compared to the type. The new variety $A$. micheliifolia var. macrospora is described in this paper.

Keywords : Black mildew, foliicolous fungi, Michelia, new variety, Western Ghats, Asteridiella
\end{abstract}

\section{INTRODUCTION}

Black mildew fungi infect many plant species of different families and form black colonies on the leaf surface of host plants. They are widely distributed in the tropics and subtropics (Hansford,1961; Hosagoudar, 2008). They are strictly obligate biotrophs, superficial, usually host specific at least at the family level or have a very narrow host range, mostly infect leaves and rarely petioles, young and soft stem of flowering plants ranging from herbs to trees (Hofmann, 2009).

Vagamon, located on the western outskirts of Idukki district, falls within Western Ghats, and has been identified as a biodiversity 'hotspot'. It is a relatively remote area in a sparsely inhabited region comprising natural landscape rich in endemic flora and fauna. This area, unique for grasslands, has an extent of 27.19 square kilometers and comprises lateritic soil type. Vagamon was a virgin, pristine forest ecosystem till recently. There were encroachments in the region from as early as in the year 1950 and thus started the deterioration of the ecosystem of this area.

A survey of the foliicolous fungal flora of Vagamon hills in Kerala state resulted in unearthing several foliicolous fungi. Of these, a new variety of Asteridiella micheliifolia var. Macrospora var. nov. is described with photomicrographs in detail.

\section{MATERIALS AND METHODS}

Infected plant parts, noticed in the field, were collected and labeled from the study area. Prior to collection, photographs were taken. The infection pattern such as pathogenicity, nature of colonies, nature of infection, etc. and geographical data such as locality and altitude were recorded in the field. Collected samples were transferred separately into clean non-contaminated polythene bags along with host twigs, preferably with reproductive parts, to facilitate the identity of host plant. Further processing of the sample was carried out in the laboratory. The samples were pressed neatly and placed in between blotting papers until dryness is attained. To study the entire colony in its natural condition, Nail polish technique was adopted (Hosagoudar and Kapoor, 1985). To avoid the colonies with hyperparasites, the infected leaves were examined under stereo microscope (Magnus). A drop of high quality well transparent nail polish was applied on the selected colonies and infected regions, so that the colonies will get firmly embedded in it and can be easily peeled out from the leaf when it dries. Embedded colonies were peeled off from the leaves and mounted on to a clean slide (Blue Star) by using a drop of DPX (Dibutylphthalate Polysterene Xylene) and a cover slip. These slides were labeled and placed in a dust free chamber for one to two days for drying. Further microscopic studies and analysis were carried out with the help of Olympus Digital Binocular Compound microscope (CX21iLED). Photomicrographs were captured by Magcam DC10 CMOS camera of 10 megapixels and measurements were taken with the help of MagVision image analyzer software. Finally, the infected plant specimens were deposited in the Mar Thoma College Herbarium, Tiruvalla (MTCHT) (regional herbarium), Kerala, India.

\section{RESULTS}

Asteridiella micheliifolia Hosag., Archana. \& Agarwal var. macrospora Jacob Thomas and Hina Mohamed var. nov.

Plate 1 (A-D)

\section{MycoBank number: MB 833615.}

Diagnosis: The diagnostic features of present variety are hypophyllous colonies, undulate mycelial hyphae, longer and broader hyphal cells $(20-34$ x 5-9 $\mu \mathrm{m})$, longer appressoria $(18-27 \mu \mathrm{m})$, larger head cells $(12-17 \times 11-16 \mu \mathrm{m})$, larger phialides $(15-22 \times 6-9 \mu \mathrm{m})$ and larger ascospores

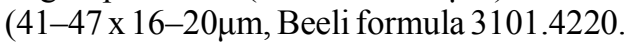

Entymology: New variety Asteridiella micheliifolia var. macrospora var. nov. is named after the larger size of ascospores.

Colonies amphigenous mostly hypophyllous, subdense, up to $9 \mathrm{~mm}$ in diameter. Hyphae undulate, branching alternate to opposite at wide angles, loosely to closely reticulate, cells 20-34 x 5-9 $\mu \mathrm{m}$. Appressoria alternate, straight to slightly curved, antrorse, $18-27 \mu \mathrm{m}$ long, stalk cells cylindrical to cuneate, $4-11 \mu \mathrm{m}$ long, head cells ovate, oblong, angular to sublobate, 12-17 x11-16 $\mu \mathrm{m}$. Phialides mixed with appressoria, alternate to opposite, ampulliform, 15-22 x $6-9 \mu \mathrm{m}$. Perithecia scattered, globose, up to $120 \mu \mathrm{m}$ in diam. Perithecial wall cells mammiform to conoid, obtuse at the tip. Ascospores obovoidal, four septate, constricted at the septa,

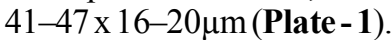




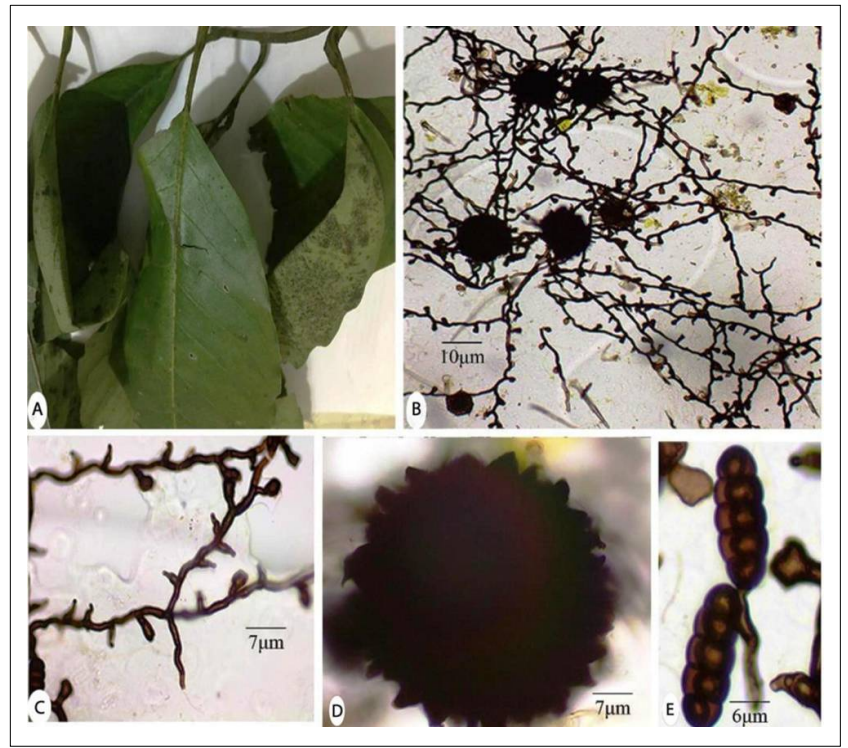

Plate-1. Asteridiella micheliifolia var. macrospora var. nov.

A. Infected leaves of Michelia champaca.

B. Colony with perithecia

C. Appresoriate mycelium with phialides

D. Mature Perithecium

E. Ascospores

Material examined: India, Kerala, Vagamon Hills, Elappara, $\mathrm{N} 9^{\circ} 38.844, \mathrm{E} 76^{\circ} 57.066,1039 \mathrm{~m}$ on the leaves of Michelia champaka, 12 December, 2018, Hina Mohamed, MTCHT147(Holotype), MTCHT 148 (Isotype).

\section{DISCUSSION}

The taxonomic details of the present fungal specimen are closely related to Asteridiella micheliifolia Hosag. et al. in having alternate to opposite branching mycelia with alternate appresoria mixed with phialides, globose perithecia and mammiform perithecial wall cells. A. micheliifolia is reported on this host genus from JNTBGRI, Palode, Thiruvananthapuram (Hosagoudar, 2013). However, the presently examined collection differs from the details of the type species, in having hypophyllous colonies, undulate mycelial hyphae, longer and broader hyphal cells (20-34 x 5-9 $\mu \mathrm{m})$, longer appressoria $(18-27 \mu \mathrm{m})$, larger head cells $(12-17 \times 11-16 \mu \mathrm{m})$, larger phialides $(15-22 \times 6-9 \mu \mathrm{m})$ and larger ascospores (41-47 $\times 16-20 \mu \mathrm{m}$ in comparison to $20-29 \times 10-12 \mu \mathrm{m}$ in the type species). The Beeli formula of current specimen (3101.4220) is also quite different from the Beeli formula of $A$. micheliifolia (3101.2220).
Meliolaceous fungi are predominantly foliicolous and rarely infect the soft stems and tender shoots. Members of Meliolales are generally shade and moisture loving, prefer $19-25^{\circ} \mathrm{C}$ temperature, $50-65 \%$ relative humidity, $40-200$ $\mathrm{mm}$ rainfall and an altitude of 100-1868 $\mathrm{m}$. Hence, they occur luxuriantly in the present study area. However, the present specimen does not have any severe and harmful pathogenic effects on the host, but it may adversely affect the photosynthetic efficiency and aesthetic beauty of the plant.

\section{CONCLUSIONS}

Anew variety of foliicolous fungus, Asteridiella micheliifolia var. macrospora var. nov. which is closely related to $A$. micheliifolia Hosag. et al. was found infecting the foliage of Michelia champaka, from Vagamon hills, Kerala. Based upon the larger ascospore size and variable Beeli formula in comparison to Asteridiella micheliifolia, a new variety has been proposed to accommodate the presently examined collection.

\section{ACKNOWLEDGEMENTS}

The authors are thankful to Dr. Icy. K. John, Principal, Mar Thoma College, Thiruvalla for providing facilities, Department of Forests and Wildlife, Govt. of Kerala for permission to enter the forested area for collecting the infected materials, KSCSTE, Govt. of Kerala and UGC, Govt. of India, New Delhi for the fellowship to conduct the research.

\section{REFERENCES}

Hansford, C.G. 1961. The Meliolaceae. A Monograph, Sydowia. Beih. 2: 1-806.

Hofmann, T.A. 2009. Plant parasitc Asterinaceae and Microthyriaceae from the Neotropics (Panama), (Ph.D. thesis). Faculty of Biological Sciences, J.W. Goethe-University, Frankfurt am Main, Germany.

Hosagoudar, V.B. 2013. Meliolales of India Volume - III. Journal of Threatened Taxa-5 (6): 4005.

Hosagoudar, V.B. 2008. Meliolales of India Volume - II. Botanical Survey of India, Calcutta. 2-3pp.

Hosagoudar, V.B. and Kapoor, J.N.1985. New technique of mounting meliolaceous fungi. Indian Phytopathol. 38: $548-549$. 